\title{
IDENTIFICATION AND OCCURRENCE OF ANTIBIOTIC RESISTANCE OF Staphylococcus aureus AND Escherichia coli ISOLATED FROM RECREATIONAL PARKS AROUND KOTA KINABALU, SABAH
}

\author{
Rajeena Sugumaran, Pamela David Jocksing and Nur Athirah Yusof' \\ Biotechnology Research Institute, \\ Universiti Malaysia Sabah, Kota Kinabalu, Sabah, Malaysia \\ *Corresponding author's email: nrathirah.yusof@ums.edu.my \\ Received date: 11 September 2019 | Accepted date: 21 January 2020
}

\section{ABSTRACT}

Staphylococcus aureus (S. aureus) and Escherichia coli (E. coli) are contributors to infection cases among the Asian population. S. aureus is found in the mucous lining of noses and is mainly non-pathogenic while E. coli, mostly harmless bacteria, are found in the intestine. Pathogenic strains of both bacteria have adverse effects on the elderly and younger age group of the population. Samples were collected from recreational parks around Kota Kinabalu as they are hotspots frequently visited by families with both age groups. The bacterial samples were isolated and cultured on selective media such as Baird-Parker agar (BPA), Brain Heart Infusion (BHI) agar, MacConkey agar and Eosin-Methylene Blue (EMB) agar. Morphological characteristics of bacterial growth were observed, where S. aureus had black-shiny growth in BPA and $E$. coli had a metallic-green sheen in EMB agar. The suspected bacteria samples were then stained and viewed under a light microscope. S. aureus was identified as gram-positive, stained violet with a circular shape and clustered appearance. $E$. coli was identified as gram-negative, stained red, rod-shaped with $2-3$ bacterial alignment. Antibiotic resistance test resulted in $S$. aureus and E. coli samples did not display $100 \%$ resistance among 4 antibiotics tested (ampicillin, penicillin, tetracycline and chloramphenicol). Most of the bacteria samples were a minimum inhibitory of 
$0.1 \mathrm{mg} / \mathrm{mL}$ of antibiotic concentration. These results provide a foundation for further research on identifying bacterial strains using molecular methods. The findings can then be used to disseminate information to the public to create awareness of potential disease outbreaks in the city.

Keywords: bacteria, recreational parks, antimicrobial resistance, Sabah, community health, infection

\section{INTRODUCTION}

Staphylococcus aureus (S. aureus) and Escherichia coli (E. coli) are contributors to cases of infection among the Asian population. Naturally, 30\% of bacteria S. aureus is found in the mucous membrane lining of noses and are mainly non-pathogenic while E. coli, mostly harmless bacteria, are found in the lower intestine of humans and animals (CDC, 2011; WHO, 2018). Humans are the major reservoir for S. aureus where it is estimated that up to half of all adults are colonized (Boucher \& Corey, 2008; Lowy, 1998). Staphylococci were first observed by Robert Koch in pus in 1878 but were only named "Staphylococcus", a Greek word that meant a bunch of grapes and "coccus" for berry by Alexander Ogston in 1882 (Bhedi, 2016). In 1884, Staphylococci was grown in pure culture for the first time by Friedrich Rosenbach and their characteristics were studied (Bhedi, 2016). E. coli, a facultative anaerobic bacteria was first isolated and named by Professor Theodor Escherich in 1885 (Lim, Yoon, \& Hovde, 2010).

The main cause of concern of both S. aureus and E. coli is their pathogenicity; whereby certain strains of the bacteria can cause infection to humans and in extreme cases, may even lead to death. Examples of infection caused by S. aureus are bacteremia or sepsis, when the bacteria that are predominantly found in the nose or skin surface, enters the bloodstream (CDC, 2011). Pneumonia occurs when the bacteria attacks patients suffering from weakened lungs, endocarditis, the infection of heart valves and osteomyelitis, infection of the bone (CDC, 2011). The pathogenic strain of S. aureus that is resistant to antibiotics are known as Methicillin-resistant Staphylococcus aureus (MRSA), Vancomycin-intermediate Staphylococcus aureus (VISA), and Vancomycinresistant Staphylococcus aureus (VRSA) (CDC, 2011). Individuals that are susceptible to Staph infection are those with weakened immune systems or have undergone surgeries or have intravenous catheters (CDC, 2011). Over 50\% of MRSA infections have been reported in Asia, Malta, North and South America (Sit et al., 2017; Stefani et al., 2012). In Malaysia, MRSA prevalence has increased from $17 \%$ in 1986 to $44.1 \%$ in 2007 (Sit et al., 2017). 
E. coli strains that are pathogenic can cause health problems such as diarrhoea if a human gets infected with the bacteria. Transmission can occur through contact with contaminated food or water, or with come in contact with faeces. Outbreaks of food contamination is a result of Shiga toxin-producing E. coli (STEC) or also known as Verocytotoxin-producing E. coli (VTEC) or Enterohemorrhagic E. coli (EHEC) (CDC, 2016). 0157 with the most commonly reported strain in the United States (CDC, 2016). Infection can occur to anyone, however children below the ages of 5, the elderly (above 65 years old) and immunocompromised people are more at risk to develop symptoms such as bloody diarrhoea and kidney failure (haemolytic uremic syndrome) (CDC, 2016). Statistics show that in the United States, around 265,000 cases of STEC infections have been reported yearly with most are caused by 0157 strains (Scallan et al., 2011).

The study conducted was aimed to isolate $S$. aureus and E. coli bacteria contaminating local recreational parks around Kota Kinabalu, Sabah using selective culture media method. Apart from that, the objective of the research was to identify the occurrence of antibiotic resistance of $S$. aureus and E. coli. Although there have been studies conducted on the occurrence of S. aureus and E. coli in food contamination around Malaysia, this is the first research of its kind to be conducted around recreational parks in Kota Kinabalu. Recreational parks are locations frequently visited by people of all ages and can be a breeding ground for bacteria as the facilities are not cleaned. The lack of proper hygiene habits and sanitation among the community could lead to the outbreak of pathogenic strains of bacteria especially among young children and the elderly. Data from this study lays the foundation for further research, which can be utilised by governmental bodies, non-governmental bodies and the community to raise awareness on public health and prevention measures on the type of bacterial strains and their antibiotic resistance abilities.

\section{MATERIALS AND METHODS}

\section{Study Site Description}

The sites chosen for this study were public playgrounds or exercise parks located in tourists or residential spots around Kota Kinabalu, Sabah. The sites selected were Tanjung Lipat (P1), Teluk Likas (P2), Perdana Park (P3), Taman Kingfisher (P4), UMS (Universiti Malaysia Sabah) (P5) and City Apartments, Inanam (P6). Tanjung Lipat, Teluk Likas and Perdana Park are popular locations for family outings, tourists' activities with nearby food stalls. These places are extremely crowded especially on weekends and public holidays. The other 3 sampling sites are located in residential areas and university campus grounds and receive slightly lesser crowd. 


\section{Sample Collection and Incubation}

Sample collection was carried out in September 2018. Sterilised tissue swabs were used to wipe across surfaces of the playgrounds and exercise equipment (horizontally and vertically) especially at hand-held areas. Rusted areas were avoided to prevent contamination in the sample. A total of 12 tissue swab samples were collected from 6 sites. Tissues were then immediately kept in a $10 \mathrm{~mL}$ Eppendorf tube that had sterilised. The samples were then incubated at $37^{\circ} \mathrm{C}$ for 24 to $48 \mathrm{~h}$ in $10 \mathrm{~mL}$ of $1 \%$ sterile peptone broth.

\section{Microbial Analysis}

\section{Plating and Isolation of Bacteria}

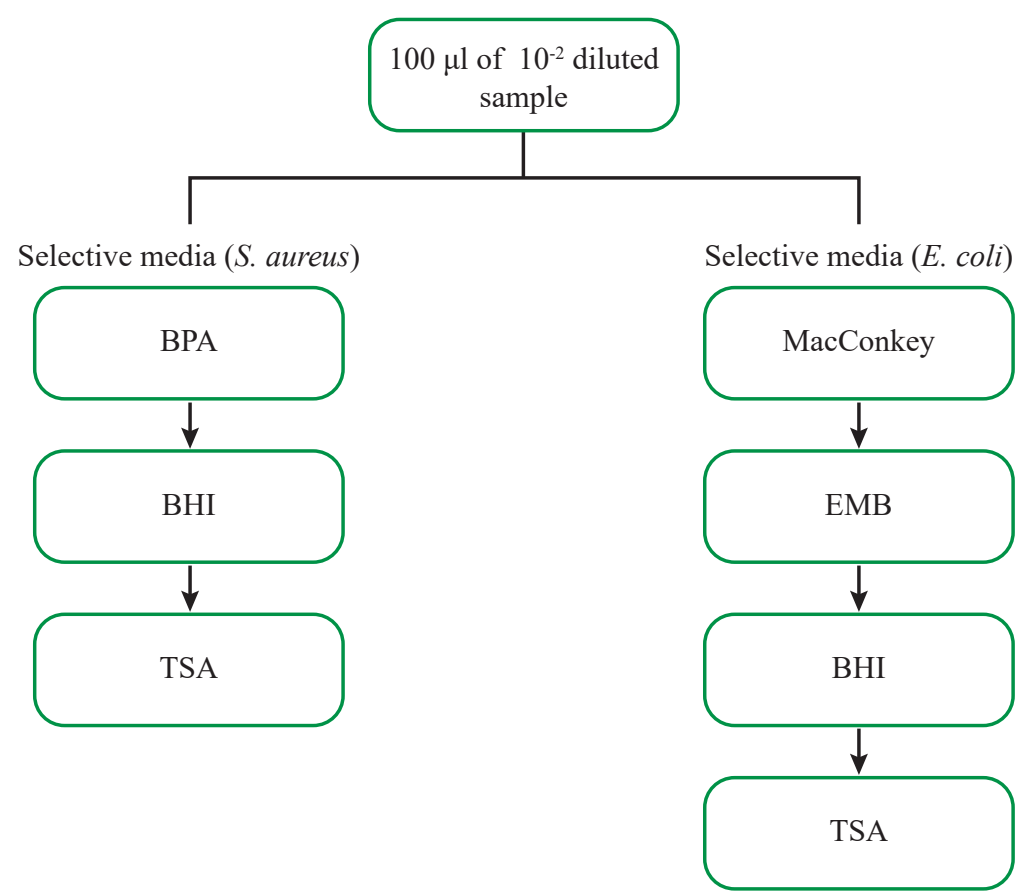

Figure 1 Summary of steps taken to isolate and identify the presence of S. aureus and E. coli in 6 samples obtained around Kota Kinabalu

For the isolation of $S$. aureus, $0.1 \mathrm{~mL}$ of diluted samples was evenly spread on plates of BPA agar (Oxoid, UK) while for the isolation of E. coli, $0.1 \mathrm{~mL}$ of diluted samples were spread on MacConkey agar (Oxoid, UK). The plates which were inoculated with the samples were incubated for 24 to $48 \mathrm{~h}$ at $37^{\circ} \mathrm{C}$. For the identification of S. aureus, single 
colonies with shiny-black growth in BPA agar were selected and then streaked on BHI agar (Oxoid, UK) media. On the other hand, for E. coli identification, single colonies with pink growth from the MacConkey media were selected and streaked on EMB agar (Oxoid, UK) plates followed by $\mathrm{BHI}$ agar plates for verification. Colour and colony growth were observed and recorded in Table 3 after each stage. Lastly, the samples were streaked on Tryptone Soy Agar (TSA) (Oxoid, UK) plates for storage and kept in $4^{\circ} \mathrm{C}$ refrigerator. The steps taken to plate and isolate the targeted bacteria were done according to the flow chart shown in Figure 1.

\section{Gram Staining}

A drop of saline was introduced on the slide. Next, a bacterial sample was smeared followed by mixing. Heat fixed was done by passing the slide through Bunsen burner. Crystal violet solution was flooded onto the slides and left to react with the specimen for $1 \mathrm{~min}$. The slides were rinsed with distilled water and then flooded with iodine solution for $1 \mathrm{~min}$. Excess iodine is rinsed off; acetone was added to decolourise the specimens for $5 \mathrm{~s}$. The slides were washed off once again using distilled water. Gramnegative bacteria are no longer visible post acetone decolourisation. Next, safranin counterstain was applied to the slides for $30 \mathrm{~s}$. The slide was washed once again with distilled water and viewed under a light microscope (Olympus, USA).

\section{Antimicrobial Susceptibility Tests}

Isolates for $S$. aureus and $E$. coli were tested for antibiotic resistance using the Kirby-Bauer disk diffusion susceptibility method. This method complied with the Clinical Laboratory Standard Institute guidelines (Yassin et al., 2017). Antimicrobial susceptibility tests were performed on Mueller Hinton $(\mathrm{MH})$ agar (Oxoid, UK) plates. The concentration gradients of antibiotics were used to determine S. aureus and $E$. coli's sensitivity and resistance are shown in Table 1. A single colony was obtained from each plate and emulsified in $1 \%$ sterile buffered peptone water. The solution was mixed thoroughly to ensure that no solid material from the colony was visible in the broth. The inoculated bacterial colonies in the broth were incubated at $37^{\circ} \mathrm{C}$ for $2 \mathrm{~h}$ to reach log phase growth. Next, $100 \mu \mathrm{L}$ of the bacteria culture were plated on $\mathrm{MH}$ agar plates and were evenly spread. The plates were dried for $5 \mathrm{~min}$ before the antibiotic discs were placed on the surface of the agar. Sterilised forceps were used. The inoculated plates were inverted and incubated at $37^{\circ} \mathrm{C}$ for $24 \mathrm{~h}$. Using a ruler, the diameter of the inhibition zones was measured for each disc and compared with the standard table to determine the sensitivity and resistance of bacteria. 
Table 1 Concentration of antibiotics used for the susceptibility test of S. aureus and E. coli

\begin{tabular}{cccc} 
Antibiotics $(\mathbf{m g} / \mathbf{m L})$ & \multicolumn{3}{c}{ Concentration $(\mathbf{m g} / \mathbf{m L})$} \\
Ampicillin & 0.1 & 1.0 & 10.0 \\
Ampicillin & 0.3 & 3.0 & 3.0 \\
Chloramphenicol & 0.1 & 1.0 & 10.0 \\
Chloramphenicol & 0.25 & 2.5 & 25 \\
Penicillin & 0.1 & 1.0 & 10.0 \\
Penicillin & 0.3 & 3.0 & 3.0 \\
Tetracycline & 0.1 & 1.0 & 10.0 \\
\hline
\end{tabular}

\section{RESULTS}

\section{Isolation and Identification of S. aureus in Culture Samples}

Based on Figure 2, positive isolation and identification of the bacteria were present in 5 out of the 6 locations which were P1 for Tanjung Lipat, P2 for Teluk Likas, P3 for Perdana Park, P4 for Taman Kingfisher and P6 for City Apartments. The bacteria growth had black colonies in BPA. Only sample P5 obtained from UMS had an absence of S. aureus. To validate further the presence of $S$. aureus, single colonies from BPA media were inoculated on $\mathrm{BHI}$ media whereby the positive presence of bacteria was seen as pale-yellowish growth as indicated in Figure 3. Yellow colony growth was also observed when single colonies of $\mathrm{S}$. aureus obtained from BHI were streaked on TSA for all 5 sites as stated in Figure 4. Summary of colonies observed is described in Table 2. 


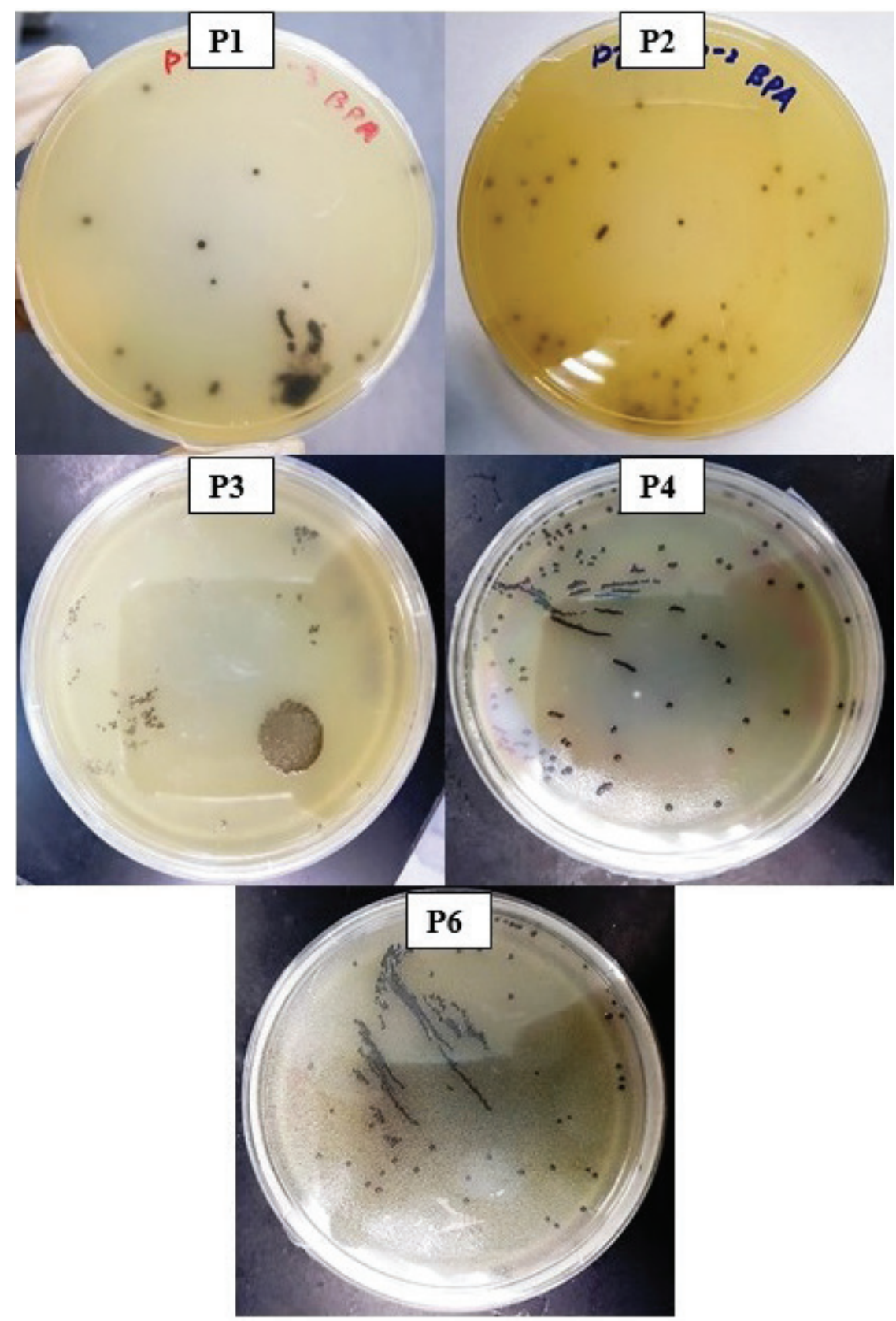

Figure 2 Isolation and identification of S. aureus growth on BPA plates. Samples obtained from P1 (Tanjung Lipat), P2 (Teluk Likas), P3 (Perdana Park), P4 (Taman Kingfisher) and P6 (City Apartments, Inanam) 

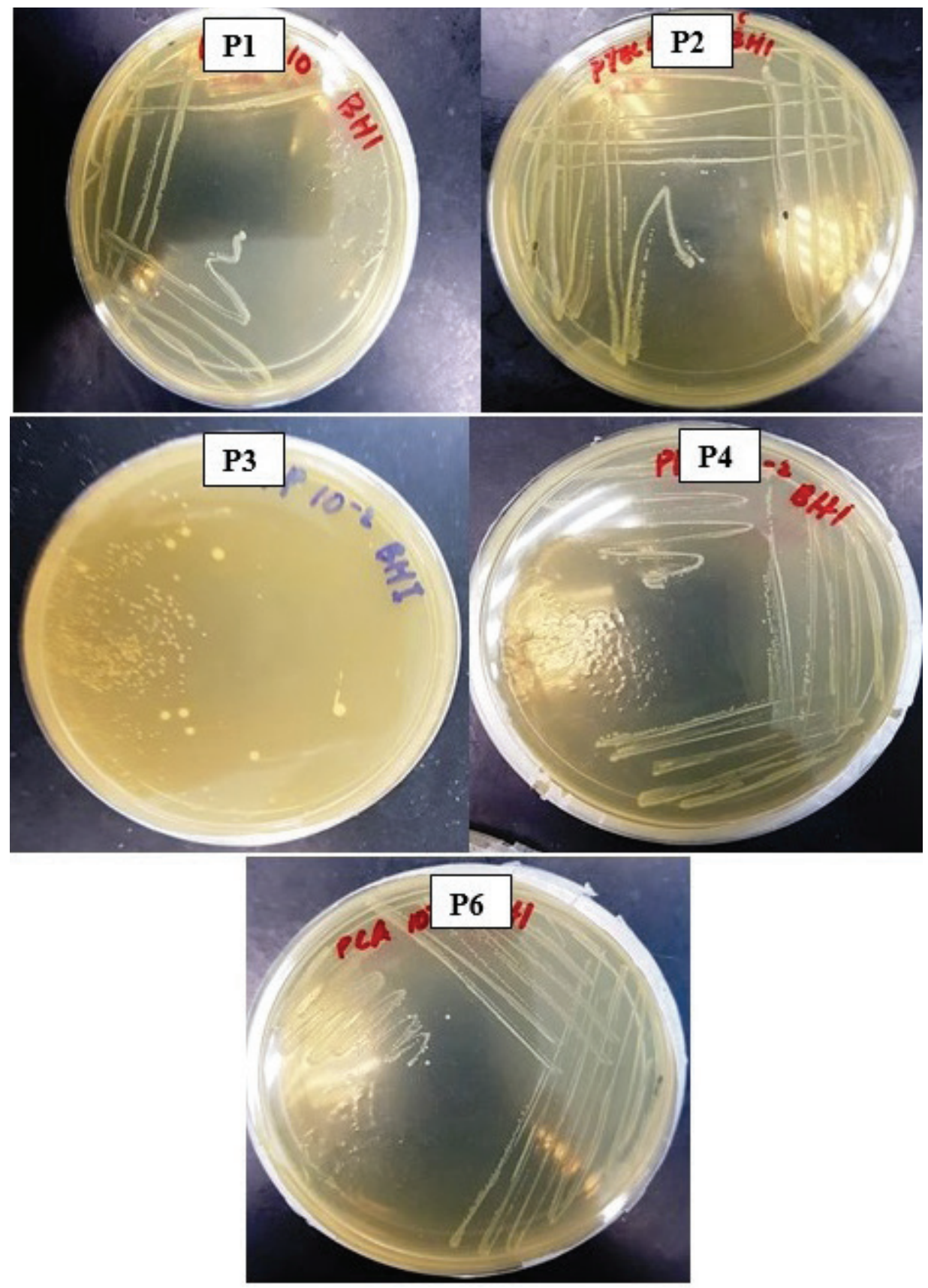

Figure 3 Isolation and identification of S. aureus growth on BHI plates labelled as P1 (Tanjung Lipat), P2 (Teluk Likas), P3 (Perdana Park), P4 (Taman Kingfisher) and P6 (City Apartments, Inanam). Samples with black-shiny colonies were selected and streaked on BHI 


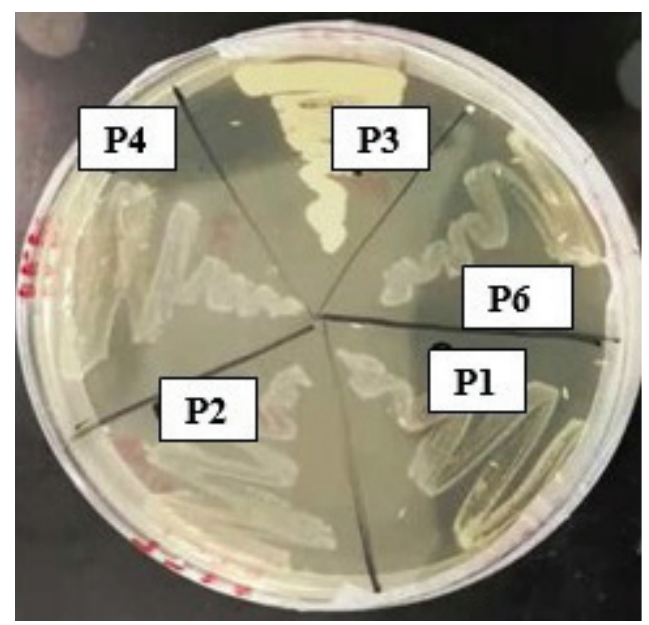

Figure 4 Isolation and identification of S. aureus growth on TSA plates. Samples were collected from 6 sampling sites; P1 (Tanjung Lipat), P2 (Teluk Likas), P3 (Perdana Park), P4 (Taman Kingfisher) and P6 (City Apartments, Inanam)

Table 2 Summary of morphological identification and isolation of bacteria using selective media from 6 sampling sites

\begin{tabular}{|c|c|c|c|c|c|c|c|c|c|}
\hline \multirow[b]{2}{*}{ Sample } & \multirow[b]{2}{*}{ Volume } & \multirow[b]{2}{*}{ Dilution } & \multicolumn{2}{|c|}{$\begin{array}{c}\text { Identification of } \\
\text { Staphylococcus aureus }\end{array}$} & \multicolumn{3}{|c|}{ Identification of Escherichia coli } & \multirow[b]{2}{*}{ TSA } & \multirow[b]{2}{*}{$\begin{array}{l}\text { Presumptive } \\
\text { isolates }\end{array}$} \\
\hline & & & BPA & BHI & MacConkey & EMB & BHI & & \\
\hline $\begin{array}{l}\text { P1 (Tanjung } \\
\text { Lipat) }\end{array}$ & $100 \mu \mathrm{L}$ & $10^{-3}$ & $\begin{array}{l}\text { POS - black, } \\
\text { circular and } \\
\text { shiny colony } \\
\text { growth. No } \\
\text { halo zone } \\
\text { observed }\end{array}$ & $\begin{array}{l}\text { POS - pale } \\
\text { yellowish } \\
\text { growth }\end{array}$ & $\begin{array}{l}\text { POS - pink, } \\
\text { non-mucoid } \\
\text { colonies }\end{array}$ & $\begin{array}{l}\text { NEG. } \\
\text { - no } \\
\text { metallic } \\
\text { green } \\
\text { sheen. } \\
\text { Mucoid } \\
\text { growth }\end{array}$ & & $\begin{array}{l}\text { POS - } \\
\text { yellowish } \\
\text { growth }\end{array}$ & $\begin{array}{c}\text { Staphylococcus } \\
\text { aureus } \\
\text { Enterobacteria } \\
\text { sp. }\end{array}$ \\
\hline $\begin{array}{l}\text { P2 (Teluk } \\
\text { Likas) }\end{array}$ & $100 \mu \mathrm{L}$ & $10^{-3}$ & $\begin{array}{l}\text { POS - black, } \\
\text { circular and } \\
\text { shiny growth. } \\
\text { No halo zone }\end{array}$ & $\begin{array}{l}\text { POS - pale } \\
\text { yellowish } \\
\text { growth }\end{array}$ & $\begin{array}{c}\text { POS - } \\
\text { pink and } \\
\text { colourless, } \\
\text { mucoid and } \\
\text { non-mucoid } \\
\text { colonies }\end{array}$ & $\begin{array}{l}\text { NEG. } \\
\text { - pink, } \\
\text { mucoid } \\
\text { growth }\end{array}$ & & $\begin{array}{l}\text { POS - } \\
\text { yellowish } \\
\text { growth }\end{array}$ & $\begin{array}{c}\text { Staphylococcus } \\
\text { aureus } \\
\text { Enterobacteria } \\
\text { sp. }\end{array}$ \\
\hline $\begin{array}{l}\text { P3 (Perdana } \\
\text { Park) }\end{array}$ & $100 \mu \mathrm{L}$ & $10^{-2}$ & $\begin{array}{c}\text { POS - } \\
\text { circular, black } \\
\text { smear }\end{array}$ & $\begin{array}{l}\text { POS - pale } \\
\text { yellowish } \\
\text { growth }\end{array}$ & $\begin{array}{c}\text { POS - pale } \\
\text { pink, mucoid }\end{array}$ & $\begin{array}{c}\text { POS - } \\
\text { metallic } \\
\text { green } \\
\text { sheen }\end{array}$ & $\begin{array}{l}\text { POS - } \\
\text { whitish } \\
\text { colony } \\
\text { growth }\end{array}$ & $\begin{array}{l}\text { POS for both } \\
\text { samples - } \\
\text { Dominant } \\
\text { whitish colony } \\
\text { - Pale cream } \\
\text { coloured } \\
\text { colonies }\end{array}$ & $\begin{array}{c}\text { Staphylococcus } \\
\text { aureus }\end{array}$ \\
\hline $\begin{array}{l}\text { P4 (Taman } \\
\text { Kingfisher) }\end{array}$ & $100 \mu \mathrm{L}$ & $10^{-3}$ & $\begin{array}{l}\text { POS - black, } \\
\text { circular and } \\
\text { shiny growth. } \\
\text { No halo zone }\end{array}$ & $\begin{array}{l}\text { POS - pale } \\
\text { yellowish } \\
\text { growth }\end{array}$ & $\begin{array}{l}\text { NEG - no } \\
\text { colony } \\
\text { growth }\end{array}$ & & & $\begin{array}{l}\text { POS - } \\
\text { yellowish } \\
\text { growth }\end{array}$ & $\begin{array}{c}\text { Staphylococcus } \\
\text { aureus }\end{array}$ \\
\hline
\end{tabular}




\begin{tabular}{|c|c|c|c|c|c|c|c|c|c|}
\hline $\begin{array}{l}\text { P5 } \\
\text { (Universiti } \\
\text { Malaysia } \\
\text { Sabah) }\end{array}$ & $100 \mu \mathrm{L}$ & $10^{-2}$ & $\begin{array}{c}\text { NEG - } \\
\text { circular, black } \\
\text { smear }\end{array}$ & & $\begin{array}{l}\text { NEG - pale } \\
\text { white } \\
\text { colonies }\end{array}$ & & & & $\begin{array}{l}\text { Unidentified } \\
\text { species }\end{array}$ \\
\hline $\begin{array}{l}\text { P6 (City } \\
\text { Apartments, } \\
\text { Inanam) }\end{array}$ & $100 \mu \mathrm{L}$ & $10^{-3}$ & $\begin{array}{l}\text { POS - black, } \\
\text { circular and } \\
\text { shiny growth. } \\
\text { No halo zone }\end{array}$ & $\begin{array}{l}\text { POS - pale } \\
\text { yellowish } \\
\text { growth }\end{array}$ & $\begin{array}{l}\text { POS - dark- } \\
\text { pink, non- } \\
\text { mucoid and } \\
\text { mucoid } \\
\text { smear }\end{array}$ & $\begin{array}{l}\text { POS - } \\
\text { metallic } \\
\text { green } \\
\text { sheen }\end{array}$ & $\begin{array}{l}\text { POS } \\
\text {-white- } \\
\text { ish } \\
\text { colony } \\
\text { growth }\end{array}$ & $\begin{array}{l}\text { POS - } \\
\text { yellowish } \\
\text { growth }\end{array}$ & 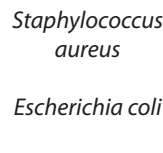 \\
\hline
\end{tabular}

Note: Bacterial colonies that grew with expected characteristics of E. coli and S. aureus were labelled as POS, while colonies which did not match the expected characteristics of $E$. coli and S. aureus were labelled as NEG.

\section{Isolation and Identification of E. coli in Culture Samples}

Successful identification of E. coli bacterial growth was found in 2 sites; P3 Perdana Park and P6 City Apartments. The bacteria were identified by their pink, mucoid and non-mucoid characteristics when grown in the MacConkey media as seen in Figure 5. Negative results occurred in the remaining sites; P1 Tanjung Lipat, P2 Teluk Likas, P4 Taman Kingfisher and P5 UMS. Validation of the bacteria was conducted by streaking single colonies taken from MacConkey agar onto EMB media and positive E. coli was indicated by a metallic sheen appearance in Figure 6. Further isolation and confirmation were done by inoculating the bacteria in BHI and TSA media where a prominent white coloured growth was observed (Figure 7) and a cream-coloured growth was seen in Figure 8. The observed characteristics of E. coli isolation were recorded in Table 2.

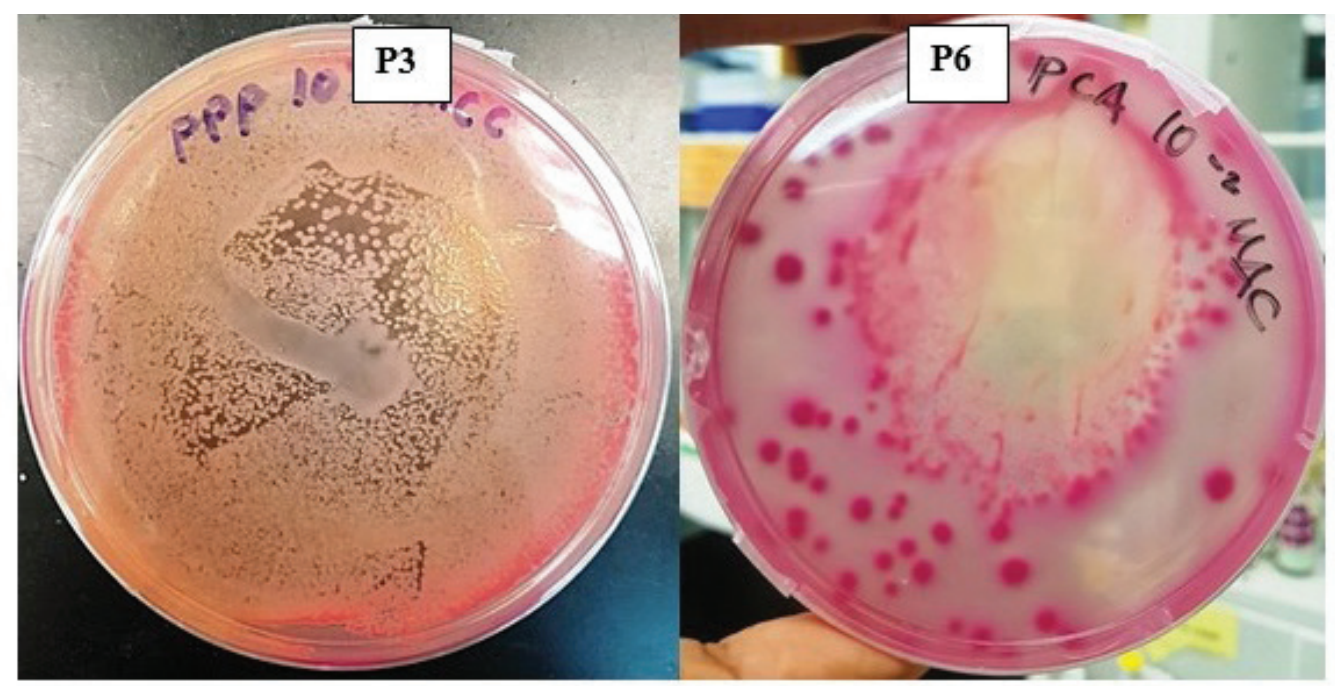

Figure 5 Isolation and identification of E. coli growth on MCC plates. Samples obtained from P3 (Perdana Park) and P6 (City Apartments, Inanam) 


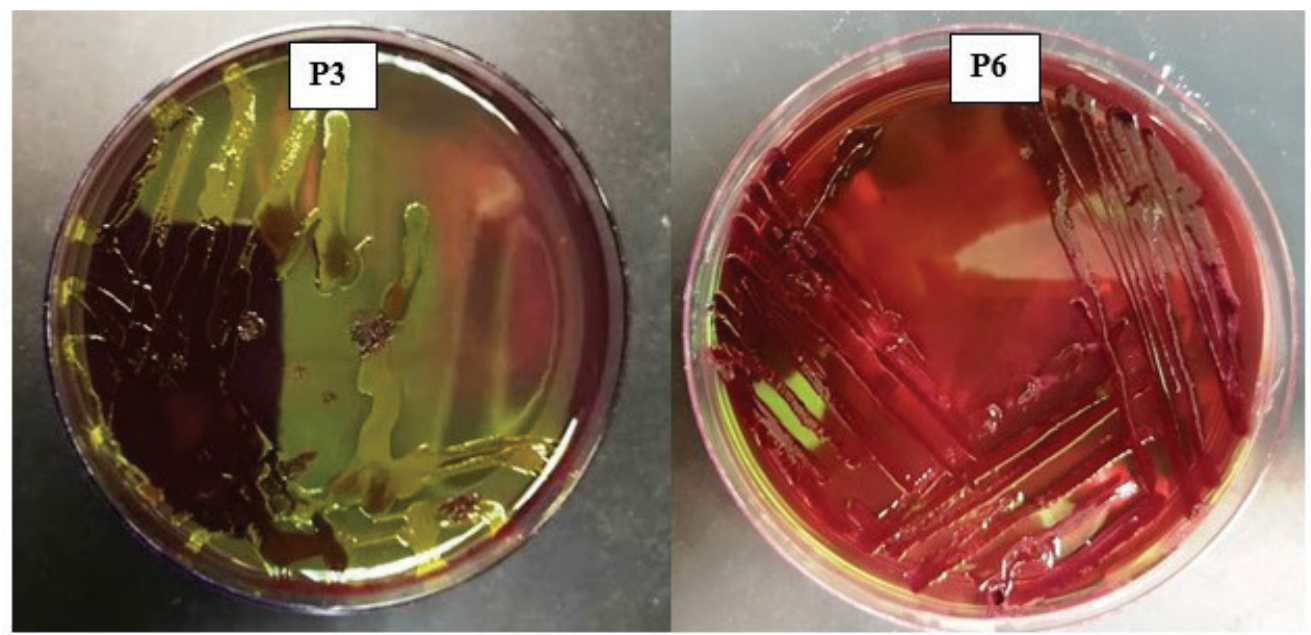

Figure 6 Isolation and identification of E. coli growth on EMB plates. Samples obtained from P3 (Perdana Park) and P6 (City Apartments, Inanam)

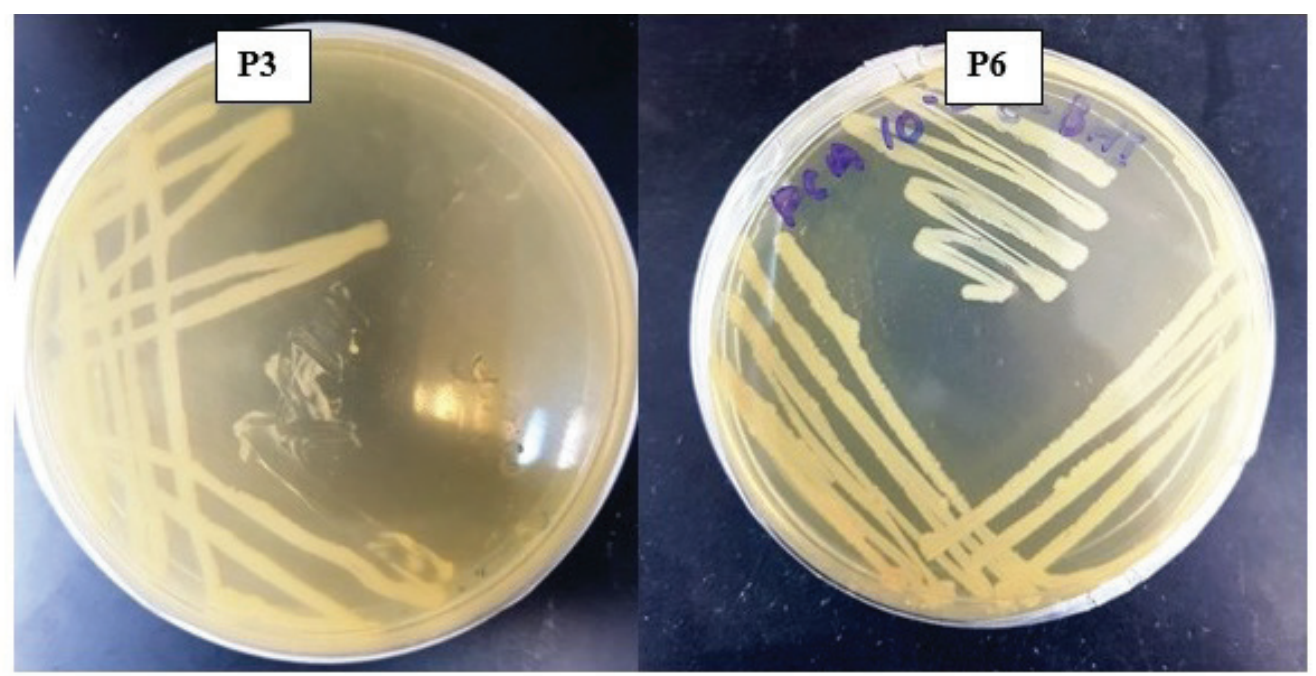

Figure 7 Isolation and identification of E. coli growth on BHI plates from P3 (Perdana Park) and P6 (City Apartments, Inanam) 


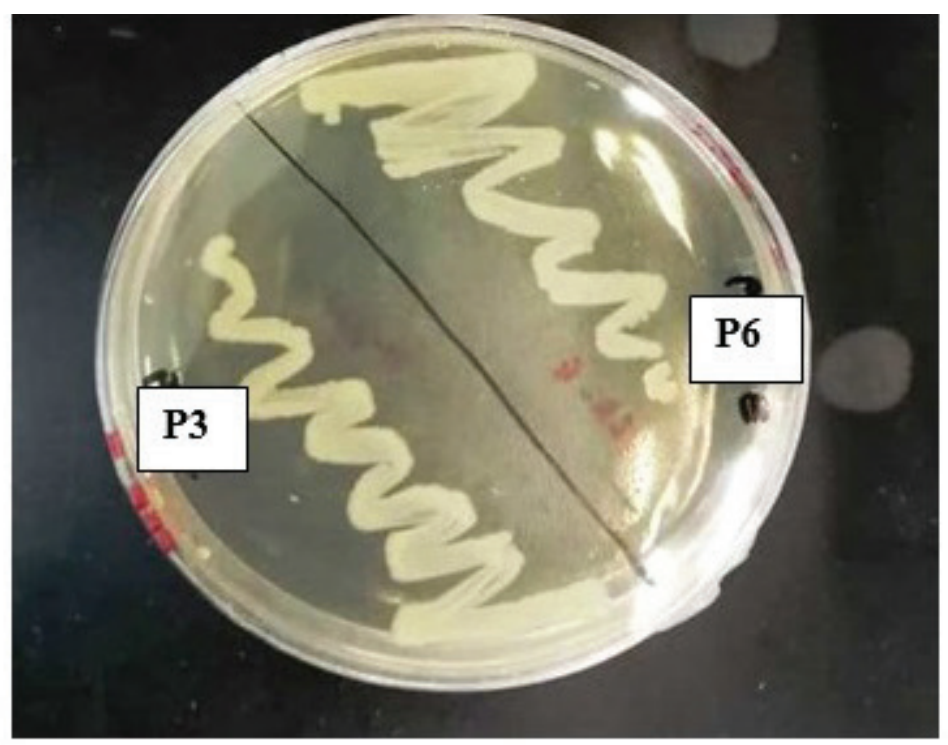

Figure 8 Isolation and identification of $E$. coli growth on TSA plates. Positive samples were identified in P3 (Perdana Park) and P6 (City Apartments, Inanam)

\section{Verification of S. aureus and E. coli using Gram Staining}

Gram staining was conducted to verify the presence of Gram-positive and Gramnegative bacteria in the isolated colonies obtained from 5 sites positive for S. aureus and E. coli. This also allowed for the observation of the bacteria's morphological characteristics. As observed in Figure 9, results were positive for the presence of $S$. aureus. The bacteria were stained violet indicating Gram-positive, had grape-like clusters and were circular shaped. Sites verified positive for S. aureus are P1 Tanjung Lipat, P2 Teluk Likas, P3 Perdana Park, P4 Taman Kingfisher and P6 City Apartments. Alternatively, E. coli is a Gram-negative bacteria where positive colonies are stained red. The results seen in Figure 10 verifies the presence of rod-shaped E. coli in P3 Perdana Park and P6 City Apartments. Summary of all verified bacterial colonies is described in Table 3. 
Table 3 Summary of the identification and morphological characteristics of Gram-positive and Gram-negative bacteria

\begin{tabular}{|c|c|c|c|c|}
\hline Sample & Bacteria & $\begin{array}{l}\text { Gram } \\
\text { Positive }\end{array}$ & $\begin{array}{c}\text { Gram } \\
\text { Negative }\end{array}$ & Morphology \\
\hline $\begin{array}{c}\text { P1 } \\
\text { (Tanjung Lipat) }\end{array}$ & $\begin{array}{c}\text { Staphylococcus } \\
\text { aureus }\end{array}$ & $x$ & & $\begin{array}{l}\text { Stained purple, grape-like } \\
\text { clusters (staphylo-). Circular } \\
\text { (coccus) shaped }\end{array}$ \\
\hline $\begin{array}{c}\text { P2 } \\
\text { (Teluk Likas) }\end{array}$ & $\begin{array}{c}\text { Staphylococcus } \\
\text { aureus }\end{array}$ & $\mathrm{x}$ & & $\begin{array}{l}\text { Stained purple, grape-like } \\
\text { clusters (staphylo-). Circular } \\
\text { shaped }\end{array}$ \\
\hline \multirow{2}{*}{$\begin{array}{c}\text { P3 } \\
\text { (Perdana Park) }\end{array}$} & $\begin{array}{c}\text { Staphylococcus } \\
\text { aureus }\end{array}$ & $x$ & & $\begin{array}{l}\text { Stained purple, grape-like } \\
\text { clusters (staphylo-). Circular } \\
\text { (coccus) shaped }\end{array}$ \\
\hline & Escherichia coli & & $x$ & $\begin{array}{l}\text { Rod-shaped, some aligned } \\
2-3 \text { together, some singular, } \\
\text { stained red }\end{array}$ \\
\hline $\begin{array}{c}\text { P4 } \\
\text { (Taman Kingfisher) }\end{array}$ & $\begin{array}{c}\text { Staphylococcus } \\
\text { aureus }\end{array}$ & $x$ & & $\begin{array}{l}\text { Stained purple, grape-like } \\
\text { clusters (staphylo-). Circular } \\
\text { (coccus) shaped }\end{array}$ \\
\hline \multirow{2}{*}{$\begin{array}{c}\text { P6 } \\
\text { (City Apartments, } \\
\text { Inanam) }\end{array}$} & $\begin{array}{c}\text { Staphylococcus } \\
\text { aureus }\end{array}$ & $\mathrm{X}$ & & $\begin{array}{l}\text { Stained purple, grape-like } \\
\text { clusters (staphylo-). Circular } \\
\text { (coccus) shaped }\end{array}$ \\
\hline & Escherichia coli & & $\mathrm{x}$ & $\begin{array}{l}\text { Singular, rod-shaped, } \\
\text { stained red. }\end{array}$ \\
\hline
\end{tabular}

\section{Antimicrobial Resistance}

E. coli and S. aureus isolates cultured from P1 Tanjung Lipat, P2 Teluk Likas, P3 Perdana Park, P4 Taman Kingfisher and P6 City Apartments were analysed for their resistance towards a range of antibiotics such as ampicillin, tetracycline, penicillin and chloramphenicol. The results of antimicrobial testing in the present study indicate that all E. coli isolates were susceptible to ampicillin. The minimum inhibitory concentration (MIC) of ampicillin which inhibited the visible growth of the bacteria was $0.3 \mathrm{mg} / \mathrm{ml}$. The diameter of the inhibition zone of $E$. coli isolates in all of the ampicillin concentration treated had a variation of $\pm 4 \mathrm{~mm}$. On the other hand, out of the $5 \mathrm{~S}$. aureus isolates, only P6 (Perdana Park) did not show any inhibition zone towards ampicillin. The MIC of S. aureus against ampicillin was mostly at $0.1 \mathrm{mg} / \mathrm{mL}$ except for P1 (Tanjung Lipat) which showed a MIC at $0.3 \mathrm{mg} / \mathrm{mL}$. The summary of the diameter of inhibition zone and MIC is described in Table 4 (a). Table 4 (b) indicates the diameter of inhibition zone for $E$. coli when treated with tetracycline had a variation of $\pm 4 \mathrm{~mm}$ between the different antibiotic concentrations. Both E. coli and S. aureus which were taken from P1 (Tanjung Lipat), P2 (Teluk Likas), P3 (Perdana Park), P4 (Taman Kingfisher) and P6 
(City Apartments) were susceptible to the lowest concentration of antibiotic which was $0.1 \mathrm{mg} / \mathrm{mL}$. S. aureus isolated from all sites except for P1 has a susceptibility to the lowest concentration of antibiotic, $0.1 \mathrm{mg} / \mathrm{mL}$ of Penicillin. The variation in diameter of inhibition zone for $E$. coli between sites P3 and P6 is $\pm 1 \mathrm{~mm}$. All E. coli isolates were susceptible to penicillin as found in Table 4 (c). All E. coli and S. aureus bacteria were susceptible to the lowest concentration of chloramphenicol tested, $0.1 \mathrm{mg} / \mathrm{mL}$. The diameter of inhibition zones increases with the increment of antibiotic concentration where at the highest concentration tested, $25 \mathrm{mg} / \mathrm{mL}$, all isolates of $S$. aureus showed an inhibition zone of $31 \mathrm{~mm} \pm 3 \mathrm{~mm}$ except for isolates from P4 (Taman Kingfisher). Results are tabulated in Table 4 (d).

Table 4 The diameter of inhibition zones $(\mathrm{mm})$ for Staphylococcus aureus and Escherichia coli according to 4 types of antibiotics (a) ampicillin, (b) tetracycline, (c) penicillin and (d) chloramphenicol according to their respective concentrations. Locations were P1 (Tanjung Lipat), P2 (Teluk Likas), P3 (Perdana Park), P4 (Taman Kingfisher), P5 (Universiti Malaysia Sabah) and P6 (City Apartments, Inanam)

\begin{tabular}{|c|c|c|c|c|c|c|c|}
\hline \multirow{2}{*}{$\begin{array}{l}\text { Ampicillin } \\
\text { concentration } \\
(\mathbf{m g} / \mathbf{m L})\end{array}$} & \multicolumn{5}{|c|}{$\begin{array}{l}\text { Diameter of inhibition zones } \\
\text { (Staphylococcus aureus) (mm) }\end{array}$} & \multicolumn{2}{|c|}{$\begin{array}{l}\text { Diameter of inhibition zones } \\
\text { (Escherichia coli) (mm) }\end{array}$} \\
\hline & P1 & P2 & P3 & P4 & P6 & P3 & P6 \\
\hline 0.1 & 0 & 11 & 22 & 16 & \multirow{6}{*}{ 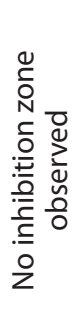 } & 0 & 0 \\
\hline 0.3 & 12 & 17 & 23 & 20 & & 11 & 8 \\
\hline 1.0 & 18 & 23 & 20 & 25 & & 15 & 11 \\
\hline 3.0 & 26 & 28 & 19 & 28 & & 23 & 24 \\
\hline 10 & 27 & 32 & 22 & 30 & & 27 & 23 \\
\hline 30 & 28 & 32 & 22 & 30 & & 30 & 26 \\
\hline
\end{tabular}

(a)

\begin{tabular}{cccccccc}
$\begin{array}{c}\text { Tetracycline } \\
\text { concentration }\end{array}$ & \multicolumn{4}{c}{$\begin{array}{c}\text { Diameter of inhibition zones } \\
\text { (Staphylococcus aureus) }(\mathbf{m m})\end{array}$} & \multicolumn{2}{c}{$\begin{array}{c}\text { Diameter of inhibition zones } \\
\text { (Escherichia coli) (mm) }\end{array}$} \\
\hline 0.1 & P1 & P2 & P3 & P4 & P6 & P3 & P6 \\
1.0 & 20 & 15 & 24 & 10 & 25 & 15 & 19 \\
10 & 27 & 13 & 34 & 12 & 31 & 26 & 24 \\
\hline
\end{tabular}

(b) 


\begin{tabular}{|c|c|c|c|c|c|c|c|}
\hline \multirow{2}{*}{$\begin{array}{l}\text { Penicillin } \\
\text { concentration } \\
\text { (mg/mL) }\end{array}$} & \multicolumn{5}{|c|}{$\begin{array}{l}\text { Diameter of inhibition zones } \\
\text { (Staphylococcus aureus) (mm) }\end{array}$} & \multicolumn{2}{|c|}{$\begin{array}{l}\text { Diameter of inhibition zones } \\
\text { (Escherichia coli) }(\mathrm{mm})\end{array}$} \\
\hline & P1 & P2 & P3 & P4 & P6 & P3 & P6 \\
\hline 0.1 & 0 & 20 & 17 & 18 & 22 & 6 & 10 \\
\hline 0.3 & 8 & 20 & 16 & 19 & 19 & 6 & 10 \\
\hline 1.0 & 11 & 27 & 22 & 25 & 25 & 9 & 10 \\
\hline 3.0 & 17 & 27 & 22 & 27 & 25 & 10 & 10 \\
\hline 10 & 20 & 30 & 26 & 25 & 27 & 21 & 22 \\
\hline 30 & 23 & 36 & 25 & 30 & 30 & 25 & 24 \\
\hline
\end{tabular}

(c)

\begin{tabular}{cccccccc}
$\begin{array}{c}\text { Chloramphenicol } \\
\text { concentration } \\
\text { (mg/mL) }\end{array}$ & \multicolumn{4}{c}{$\begin{array}{c}\text { Diameter of inhibition zones } \\
\text { (Staphylococcus aureus) }(\mathbf{m m})\end{array}$} & $\begin{array}{c}\text { Diameter of inhibition zones } \\
\text { (Escherichia coli) }(\mathbf{m m})\end{array}$ \\
\hline 0.1 & P1 & P2 & P3 & P4 & P6 & P3 & P6 \\
0.25 & 12 & 14 & 14 & 15 & 10 & 6 & 11 \\
1.0 & 16 & 14 & 16 & 15 & 8 & 11 & 5 \\
2.5 & 16 & 24 & 22 & 19 & 20 & 23 & 14 \\
10 & 24 & 24 & 20 & 19 & 20 & 27 & 20 \\
25 & 30 & 30 & 30 & 21 & 25 & 31 & 35 \\
\hline
\end{tabular}

(d)

\section{DISCUSSION}

\section{Isolation and identification of S. aureus and E. coli from Recreational Parks}

Bacterial isolation was conducted using selective media that enabled the proliferation of target microorganism and suppressed unintended microorganisms on the medium. Based on Table 2, the presence of suspected S. aureus can be identified from black colony growth on BPA due to tellurite reduction activity. Some colonies have a clear zone surrounding them due to lecithinase production or an opaque zone of precipitation that is caused by lipase activity by coagulase-positive strains (El-Hadedy \& El-Nour, 2012; Ribeiro de Souza da Cunha, 2018). However, there was no indication of halo zone surrounding the bacteria cultures. The components inside the BPA medium are lithium chloride, potassium tellurite and egg yolk (Ribeiro de Souza da Cunha, 2018). Tellurite forming colonies are reduced by the presence of salt and potassium tellurite in the media yolk (Ribeiro de Souza da Cunha, 2018). All samples except for P5 (UMS) that had black, shiny colonies in BPA media were 
steaked onto $\mathrm{BHI}$ plates to provide enrichment for the bacterial culture (Palilu \& Budiarso, 2017). BHI media provided a nutrient-rich environment for Streptococci which is commonly challenging to grow. The results indicated that samples obtained from P1 (Tanjung Lipat), P2 (Teluk Likas), P3 (Perdana Park), P4 (Taman Kingfisher) and P6 (City Apartments, Inanam) were positive for S. aureus isolated. This probably happened due to the location of the sites where all except P5 UMS were located in the public areas that were frequently visited by people while P5 UMS was located on university campus grounds that were only accessible to students and lecturers.

Next, identification and isolation of E. coli were done in 3 stages, using MacConkey agar where successful growth of bacteria was pink, with mucoid and non-mucoid substances. The MacConkey agar is a differential medium that contains crystal violet and bile salts to inhibit the growth of any Gram-positive bacteria (Black, 2004). The agar also contains sugar lactose and a pH indicator that differentiates Enterobacteria from lactose fermenter colonies as red to non-lactose fermenting bacteria as pale (Black, 2004; Hart \& Shears, 2004). In Figure 3, samples P1, P2, P3 and P6 indicate the presence of lactose and non-lactose fermenters. Next, the suspected $E$. coli samples that were cultured in EMB agar displayed a metallic green sheen reflective to light. El-Hadedy \& El-Nour (2012) also had the same observation. Some lactose-fermenting bacteria would also produce flat, dark colonies with a green metallic sheen (as shown in P3 of Figure 3) (Acharya, 2013). The growth colonies in P1 and P2 could also be nonlactose fermenters of Gram-negative bacteria as they appear pink (Acharya, 2013). Streaking on BHI agar were only carried out using sample P3 (Perdana Park) and P6 (City Apartments) that had a metallic sheen as an indication of E. coli. The presence of E. coli bacteria in these 2 locations could be a result of nearby food stalls in the vicinity and the high density of visitors to the area.

Gram staining was conducted to differentiate the components found in the cell wall of bacteria (Bruckner, 2016). Bacteria are categorised into 4 groups; Gram-positive that are stained violet or purple due to the thick peptidoglycan layer $(60-90 \%)$ in the cell wall while Gram-negative bacteria are stained red due to a thinner layer of peptidoglycan in the cell wall (Bruckner, 2016). The other 2 categories are gram variable, where the microorganisms are unevenly stained red and violet, and gram non-reactive where the microorganisms are either poorly stained or not stained at all (Black, 2004). The Gram staining method was devised in 1884 by a Danish physician named Hans Christian Gram (Black, 2004). Observations from Table 3 and Figure 10 showed that P3 (Perdana Park) and P6 (City Apartment) samples were positive for Gramnegative bacteria, E. coli based on their rod shape and stain colour red. Gram-negative bacteria are stained red due to the inability of the thin peptidoglycan layer (10 - 20\%) 
in the cell wall to retain crystal violet colour (Bruckner, 2016; Black, 2004). During the staining process, the crystal violet colour is washed off using a decolouriser (Bruckner, 2016). The decolouriser contains acetone that degrades the outer membrane causing the colour to be washed off. Safarin (red dye) is then added and is easily absorbed by the decolourised Gram-negative bacteria (Bruckner, 2016). Sample P3 was stained violet instead of red possibly due to errors during the decolourization stage, whereby acetone was either washed off too soon before it could degrade the membrane layer or high concentration of crystal violet and iodine was used. Another possibility is that the bacteria become Gram variable if they are cultured longer than $48 \mathrm{~h}$ due to the changes in their cell wall components (Black, 2004). Table 3 and Figure 9, on the other hand, showed samples from P1, P2, P3, P4 and P6 containing Gram-positive bacteria, S. aureus, in circular, grape-like clusters. The bacteria were stained purple due to the thick peptidoglycan layer with attached teichoic acid polymers (Hart \& Shears, 2004). No Gram staining was done on P5 as the colony growth in the selective media did not resemble the morphological characteristics of S. aureus or E. coli.

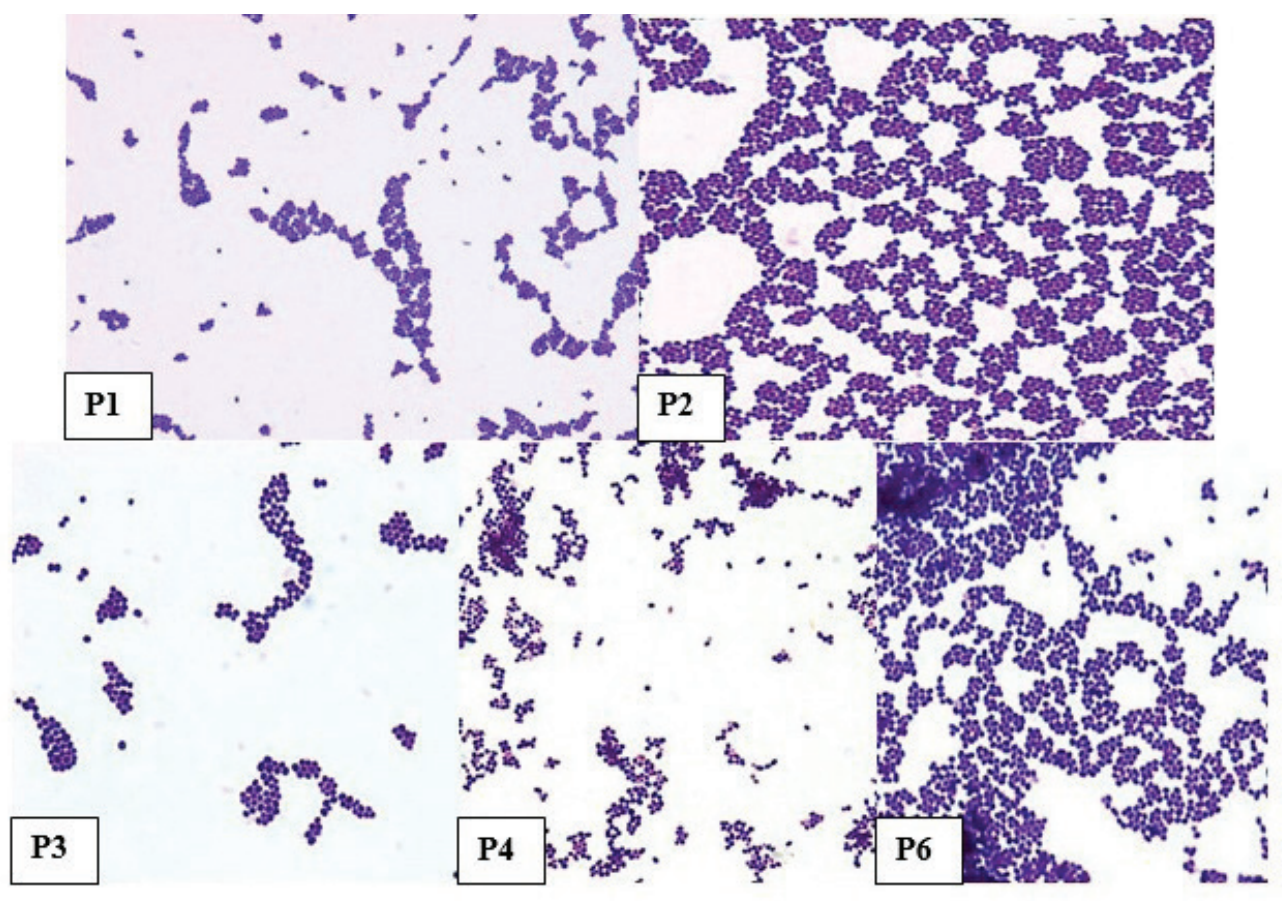

Figure 9 Gram-positive staining for bacteria S. aureus in 5 samples P1 (Tanjung Lipat), P2 (Teluk Likas), P3 (Perdana Park), P4 (Taman Kingfisher) and P6 (City Apartments, Inanam). Images were viewed under $1000 \times$ total magnification using a compound light microscope 


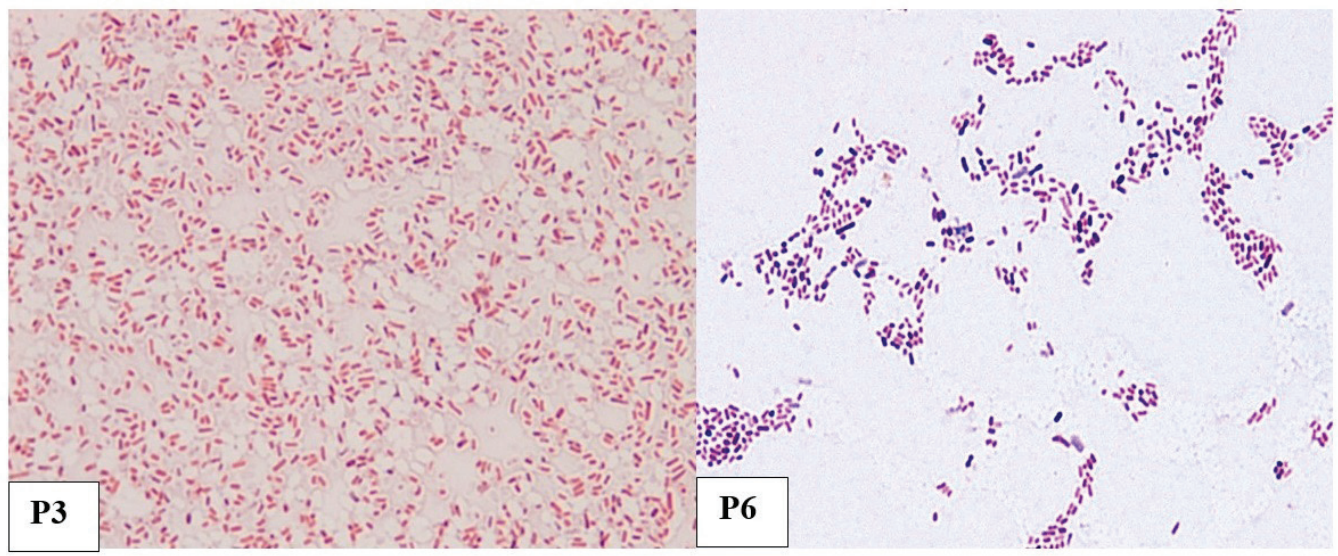

Figure 10 Gram-negative staining for E. coli in 2 samples P3 (Perdana Park) and P6 (City Apartments, Inanam). Images were viewed under $1000 \times$ total magnification using a compound light microscope

\section{Antimicrobial Susceptibility Test}

Minimum inhibitory concentration (MIC) is used to identify the lowest concentration of antibiotic that will inhibit bacterial growth in the culture media (Street, 2014). Analysis of the other antibiotics revealed that all of the S. aureus from 4 locations sampled were susceptible to ampicillin, tetracycline, penicillin and chloramphenicol. This data is important as it shows that these parks are safe for children. Dangerous $S$. aureus isolates that are increasing their multi-resistance towards modern-day drugs such as Methicillin-resistant S. aureus (MRSA), Vancomycin-Intermediate S. aureus (VISA) and Vancomycin-Resistant S. aureus (VRSA) have recorded outbreaks globally since the 1970s. Multi-resistance S. aureus was once confined largely to hospitals, health care environments, and patients frequenting these facilities, however, since the 1990s, there has been an explosion in the number of infections among the general population with and without exposure to the health care environment (Chambers \& Deleo, 2009; David \& Daum, 2010). S. aureus isolated from P1 (Tanjung Lipat) has already shown resistance towards low doses of ampicillin and penicillin both at $0.1 \mathrm{mg} / \mathrm{ml}$. This is an indicator for the public to be aware and cautious of a potential outbreak of multi-resistant Staphylococcus. Chen and Huang (2014) have reported that Malaysia had 13 cases of MRSA infections from a study period of 2006 - 2007. They have also identified that the increasing rates of MRSA infection in Asian communities have caused an increased usage of glycopeptides as an anti-MRSA agent which has indirectly caused glycopeptide-non-susceptible stains to develop. The densely populated Asian communities also contribute to the infection spreading easily from one infected individual to another. 
Results in Table 3 identified E. coli isolates from P3 (Perdana Park) and P6 (City Apartments) were resistant to $0.1 \mathrm{mg} / \mathrm{mL}$ of ampicillin but were susceptible to tetracycline, penicillin and chloramphenicol at all tested concentrations. Tanih, Sekwadi, Ndip, and Bessong (2015) reported that S. aureus and E. coli identified in their research showed $100 \%$ susceptibility for ampicillin which was not the case for the current study. This goes to show that antibiotic susceptibility varies with time and location (Tanih et al., 2015).

The overall results show that P6 (City Apartments) had both resistant strains of $S$. aureus and E. coli towards low dose of antibiotics. This is an important finding as the site is a residential location where children frequently play at the playground. The low hygiene level and awareness at the residential area could have contributed to a mutated strain of bacteria and immediate action needs to be taken by the community or city council to clean the playground facilities.

There are several limitations of the research in identifying the type of S. aureus and $E$. coli bacteria found. Observation of phenotypic characteristics alone is insufficient to confirm the presence of bacteria. Further differentiation tests can be carried out using biochemical tests such as catalase and coagulase tests to differentiate Streptococci and Staphylococci, indole or methyl red test to differentiate $E$. coli from other Enterobacteriaceae (Hart \& Shears, 2004). DNA sequencing should be carried out to identify the exact species and strain of bacteria present. The results from this research serve only for laboratory reference and to act as a foundation to initiate further research. The identification of bacteria must be conducted as $S$. aureus infection could start with blisters or pus-filled boils on the skin (Kaiser, 2016). The bacteria can spread if anyone comes in contact with the pus, and on rare occasions, further infection such as meningitis, septicaemia, septic arthritis, endocarditis and osteomyelitis could occur (Kaiser, 2016). The test on antibiotic susceptibility would help to identify resistant bacterial strains for the detection and prevention of MRSA. The findings from in-depth research can then be used by the health department and for public awareness on the possibilities of pathogenic bacteria spread amongst children in the playground. The outcome serves as a reminder of the importance of proper hygiene habits to prevent the spread of transmissible diseases.

\section{CONCLUSION}

Managing contamination of $S$. aureus and $E$. coli in recreational park facilities is definitely a challenge. Recreational parks are public amenities and the spread of germs and bacteria are highly significant to all users. Awareness needs to be instilled in the community on the importance of personal hygiene not only before and after handling of food but also after using the park facilities. Handwashing or even the usage of hand sanitisers are an effective and inexpensive way to prevent transmission 
and infection. In conclusion, further identification and confirmation of bacterial strains via molecular methods by the identification of $16 \mathrm{~S}$ rRNA is highly recommended before informing the healthcare industry and the community to prevent potential pathogenic outbreaks in the city.

\section{ACKNOWLEDGEMENTS}

Gratitude to Biotechnology Research Institute (BRI) for allowing to use their resources and facilities for this experiment.

\section{REFERENCES}

Acharya, T. (2013). Eosin Methylene Blue (EMB) agar: Composition, uses and colony characteristics. Retrieved from https://microbeonline.com/eosin-methylene-blueemb-agar-composition-uses-colony-characteristics/

Bhedi, K. (2016). Isolation and identification of Staphylococcus aureus from poultry and poultry house environment with special reference to MRSA (Master Thesis). Department of Veterinary, Public Health and Epidemiology, College of Veterinary Science and Animal Husbandry. Gujarat: Anand Agricultural University.

Black, J. G. (2004). Microbiology: Principles and explorations (6th ed.). Virginia, United States of America: John Wiley \& Sons, INC.

Boucher, H. W., \& Corey, G. R. (2008). Epidemiology of methicillin-resistant Staphylococcus aureus. Clinical infectious diseases, 46 (Supplement 5), S344 - S349.

Bruckner, M. Z. (2016). Microbial life: Educational resources. gram staining. Retrieved from https://serc.carleton.edu/microbelife/research_methods/microscopy/gramstain. html

Chambers, H. F., \& Deleo, F. R. (2009). Waves of resistance: Staphylococcus aureus in the antibiotic era. Nature reviews. Microbiology, 7 (9), $629-641$.

Chen, C. J., \& Huang, Y. C. (2014). New epidemiology of Staphylococcus aureus infection in Asia. Clinical Microbiology and Infection, 20 (7), 605 - 623.

Centre for Disease Control and Prevention (CDC). (2011). Staphylococcus aureus in healthcare settings. Retrieved from https://www.cdc.gov/hai/organisms/staph.html

Centre for Disease Control and Prevention (CDC). (2016). Escherichia coli. Retrieved from https://www.cdc.gov/ecoli/pdfs/CDC-E.-coli-Factsheet.pdf

David, M. Z., \& Daum, R. S. (2010). Community-associated methicillin-resistant Staphylococcus aureus: epidemiology and clinical consequences of an emerging epidemic. Clinical Microbiology Reviews, 23 (3), $616-687$.

El-Hadedy, D., \& Abu El-Nour, S. (2012). Identification of Staphylococcus aureus and Escherichia coli isolated from Egyptian food by conventional and molecular methods. Journal of Genetic Engineering and Biotechnology, 10 (1), 129 - 135.

Hart, T., \& Shears, P. (2004). Colour atlas of medical microbiology (2nd ed.). United Kingdom: Mosby. 
Kaiser, G. (2016). Isolation and identification of Staphylococci. Retrieved from https://bio. libretexts.org/Demos\%2C_Techniques\%2C_and_Experiments/Microbiology_Labs_ II/Lab_15\%3A_Isolation_and_Identification_of_Staphylococci

Lim, J. Y., Yoon, J., \& Hovde, C. J. (2010). A brief overview of Escherichia coli O157: H7 and its plasmid O157. Journal of Microbiology and Biotechnology, 20 (1), 5 - 14.

Lowy, F. D. (1998) Staphylococcus aureus infections. N. Engl. J. Med., 339 (8), 520 - 532.

Palilu, P. T., \& Budiarso, T. Y. (2017). Isolation and identification of Staphylococcus sp. in powdered infant milk. AIP Conference Proceedings 1844, 020016.

Ribeiro de Souza da Cunha, M. (2018). Chapter 6: Methods for the identification, characterization, and tracking the spread of Staphylococcus aureus. In A. Fetsch (Ed.), Staphylococcus aureus (pp. 105 - 125). Cambridge, MA: Academic Press.

Scallan, E., Hoekstra, R. M., Angulo, F. J., Tauxe, R. V., Widdowson, M. A., Roy, S. L., ... Griffin, P. M. (2011). Foodborne illness acquired in the United States - major pathogens. Emerging Infectious Diseases, $17(1), 7$.

Sit, P. S., Teh, C. S. J., Idris, N., Sam, I. C., Syed Omar, S. F., Sulaiman, H., ... Ponnampalavanar, S. (2017). Prevalence of methicillin-resistant Staphylococcus aureus (MRSA) infection and the molecular characteristics of MRSA bacteraemia over a two-year period in a tertiary teaching hospital in Malaysia. BMC Infectious Diseases, 17 (1), 274.

Stefani, S., Chung, D. R., Lindsay, J. A., Friedrich, A. W., Kearns, A. M., West, H., \& Mackenzie, F. M. (2012). Methicillin-resistant Staphylococcus aureus (MRSA): Global epidemiology and harmonization of typing methods. International Journal of Antimicrobial Agents, 39 (4), $273-282$.

Street, T. (2014). Antimicrobial susceptibility. Retrieved from https://emedicine.medscape.com/ article/2103786-overview

Tanih, N. F., Sekwadi, E., Ndip, R. N., \& Bessong, P. O. (2015). Detection of pathogenic Escherichia coli and Staphylococcus aureus from cattle and pigs slaughtered in abattoirs in Vhembe District, South Africa. The Scientific World Journal.

WHO. (2018). E. coli. Retrieved from http://www.who.int/news-room/fact-sheets/detail/e-coli

Yassin, A. K., Gong, J., Kelly, P., Lu, G., Guardabassi, L., Wei, L., ... Wang, C. (2017). Antimicrobial resistance in clinical Escherichia coli isolates from poultry and livestock, China. PLoS ONE, 12 (9): e0185326. 
